\title{
Natural and experimental poisoning by Cestrum laevigatum (Solanaceae) among cattle in the Agreste region of Paraíba, Brazil
}

\author{
Intoxicação natural e experimental por Cestrum laevigatum \\ (Solanaceae) em bovinos no Agreste da Paraíba, Brasil
}

\author{
Temístocles Soares de Oliveira Neto ${ }^{1 *}$; Franklin Riet-Correa ${ }^{2}$; \\ Francisca Maria Sousa Barbosa ${ }^{3}$; Carlos Magno Bezerra de Azevedo Silva \\ Michele Flávia Sousa Marques ${ }^{4}$; Gilzane Dantas Nóbrega ${ }^{5}$; \\ Sara Vilar Dantas Simões ${ }^{6}$; Ricardo Barbosa Lucena ${ }^{6}$
}

\begin{abstract}
An outbreak of natural poisoning by Cestrum laevigatum was reported among cattle in the Agreste region of Paraíba, which affected six out of 20 animals. Four animals were found dead and two presented clinical signs, including, dyspnea, drooling, jugular vein engorgement, muscle tremors and ataxia, which subsequently progressed to recumbence and death. An experimental poisoning was performed in two bovines who were administered single doses of $35 \mathrm{~g} \mathrm{~kg}^{-1}$ and $50 \mathrm{~g} \mathrm{~kg}^{-1}$ body weight (BW), respectively, of fresh leaves and fruits. The animal that received $35 \mathrm{~g} \mathrm{~kg}^{-1} \mathrm{BW}$ had mild clinical signs, consisting of apathy, salivation and reduced ruminal movements with recovery 30 hours after the onset of initial signs. The animal that received $50 \mathrm{~g} \mathrm{~kg}^{-1} \mathrm{BW}$ showed apathy, dry stool, drooling, hyperexcitability, head pressing, opisthotonos, nystagmus, miosis, jugular and episcleral vessel engorgement, ruminal atony, muscle tremors, ataxia, falling, seizures, and sternal recumbence, followed by lateral recumbence, with death occurring 21 hours and 37 minutes after ingestion. The enzyme activities of aspartate aminotransferase and gamma-glutamyltransferase in the serum increased significantly 18 hours after the administration of the plant. The primary gross lesions in the natural and experimental cases were enlarged livers, with rounded edges and accentuation of the lobular pattern on the capsular and cut surfaces. Histopathology revealed diffuse centrilobular coagulative necrosis with hemorrhages and congestion, and the presence of degenerated hepatocytes in the midzonal regions. Based on the epidemiological and clinicopathological data, we concluded that $C$. laevigatum was responsible for an acute hepatotoxic disease among cattle in the Agreste region of Paraíba.
\end{abstract}

Key words: Cattle disease. Hepatotoxic plant. Liver damage.

\section{Resumo}

Relata-se um surto de intoxicação natural por Cestrum laevigatum em bovinos na Região Agreste da Paraíba que acometeu seis bovinos de um grupo de 20. Quatro animais foram encontrados mortos e

\footnotetext{
${ }^{1}$ Discente, Programa de Pós-Graduação em Medicina Veterinária, Universidade Federal de Campina Grande, UFCG, Patos, PB, Brasil. E-mail: temivet@hotmail.com

2 Prof. Dr., Programa de Pós-Graduação em Medicina Veterinária, UFCG, Patos, PB, Brasil. E-mail: franklin.riet@pq.cnpq.br

${ }^{3}$ Médica Veterinária, Hospital Veterinário, Universidade Federal da Paraíba, UFPB, Areia, PB, Brasil. E-mail: franciscaaraguaia@, gmail.com

${ }^{4}$ Médicos Veterinários, Centro de Ciências Humanas, Sociais e Agrárias, UFPB, Bananeiras, PB, Brasil. E-mail: azevedo@cchsa. ufpb.br; michele_flavia4@hotmail.com

5 Médica Veterinária, Hospital Veterinário, UFCG, Patos, PB, Brasil. E-mail: gil_nobrega@hotmail.com

${ }^{6}$ Profs. Drs., Hospital Veterinário, UFPB, Areia, PB, Brasil. E-mail: saravdsimoes@gmail.com; lucena.rb@gmail.com

* Author for correspondence
} 
dois apresentando sinais clínicos, com dispneia, hipersalivação, ingurgitamento das jugulares, tremores musculares e incoordenação, evoluindo para decúbito e morte, sendo posteriormente submetidos à necropsia. Foi realizada a intoxicação experimental em dois bovinos que receberam doses únicas, correspondente a $35 \mathrm{~g} \mathrm{~kg}^{-1}$ e $50 \mathrm{~g} \mathrm{~kg}^{-1}$ de peso corporal (PC) de folhas e frutos frescos. O bovino que recebeu $35 \mathrm{~g} \mathrm{~kg}^{-1} \mathrm{PC}$ apresentou alterações clínicas leves, que consistiam em apatia, salivação e redução dos movimentos ruminais com recuperação 30 horas após o início dos sinais. Já no bovino que recebeu $50 \mathrm{~g} \mathrm{~kg}^{-1}$ PC observou-se apatia, ressecamento das fezes, hipersalivação, hiperexcitabilidade, pressão da cabeça contra objetos, opistótono, nistagmo, miose, ingurgitamento das jugulares e dos vasos episclerais, atonia ruminal, tremores musculares, quedas, incoordenação, convulsões e decúbito esternal, seguido de decúbito lateral com morte $21 \mathrm{~h}$ e $37 \mathrm{~min}$ após a administração da planta. As atividades séricas de aspartato aminotransferase e gama-glutamiltransferase começaram a apresentar alterações significativas 18 horas após a administração da planta. As principais alterações macroscópicas nos animais naturalmente e experimentalmente intoxicados foram observadas no fígado, caracterizando-se por aumento de volume do órgão, com bordas arredondadas e com acentuação do padrão lobular na superfície capsular e de corte. A avaliação histopatológica revelou necrose de coagulação centrolobular difusa, associada a hemorragias e congestão, com degeneração dos hepatócitos das regiões mediozonais. Com base nos dados epidemiológicos e clínico-patológicos, conclui-se que C. laevigatum é responsável por doença hepatotóxica aguda em bovinos no Agreste da Paraíba.

Palavras-chave: Doença de bovinos. Planta hepatotóxica. Lesão hepática.

\section{Introduction}

Cestrum laevigatum Schlecht(synonym: Cestrum axillare) is a shrub in the family Solanaceae that grows up to $3 \mathrm{~m}$ tall with slightly yellowish flowers and whose natural habitats are wet open spaces, including, along the margins of streams and rivers, and at the edges of woods and marshes. In Brazil, this species is found in the Southeast, Central-West and Northeast regions, where it is referred to by the more common names of "coerana", "corana", "dama da noite" (lady of the night), among others (PEREIRA, 1992).

Although C. laevigatum is distributed in many areas of Northeast Brazil (TOKARNIA et al., 2012) and should be considered an important toxic plant that causes natural poisoning in cattle (BARBOSA et al., 2007), only a few cases of natural poisoning have been reported previously. In the Northeastern region, there has only been one report of poisoning by this plant among the dairy cattle in the Agreste region of the State of Pernambuco (COUTINHO et al., 2013).

The main factors attributing to the incidence of natural poisoning are the presence of $C$. laevigatum in pastures with scarce forage and the ingestion of its immature plants along with the young shoots and fruits (THORBURN, 1934; TOKARNIA et al., 2012). Although poisoning occurs mainly in cattle (DÖBEREINER et al., 1969), there have also been reports of poisonings in buffalos (BARBOSA et al., 2010) and goats (BRITO et al., 2010; PEIXOTO et al., 2000). Poisoning has been experimentally reproduced in cattle (DÖBEREINER et al., 1969), buffalo (BARBOSA et al., 2010), sheep (LUGT et al., 1992; THORBURN, 1934), and goats (MENEZES, 1982; PEIXOTO et al., 2000). Experimental poisoning can be reproduced with single doses varying from 10 to $50 \mathrm{~g} \mathrm{~kg}^{-1}$ body weight (BW) of the immature plant with young leaves (TOKARNIA et al., 2012).

The primary lesions associated with $C$. laevigatum poisoning is acute liver failure due to hepatocellular necrosis. The first clinical signs are observed 15 to 24 hours after ingestion of the plant, and include apathy, anorexia, ruminal arrest, arched back, constipation, dry stools containing mucus and blood, and sometimes drooling. In some animals, muscle tremors and neurological signs such as ataxia, excitation, and aggressiveness can be observed, which progress to recumbence and death that occurs between 6 and 48 hours after the initial clinical signs. Primary gross lesions are found in the liver, whose cut surfaces show accentuation of 
the lobular pattern. On histological examination, the liver shows marked centrilobular necrosis associated with congestion and hemorrhages, as well as vacuolar degeneration in the hepatocytes of the intermediate zone (DÖBEREINER et al., 1969; TOKARNIA et al., 2012).

Considering several reports from practitioners and farmers of cases of cattle death after acute disease, the objectives of this paper are to report outbreaks of natural poisoning caused by $C$. laevigatum in cattle in this region, as well as to verify the toxicity of the plant under experimental conditions.

\section{Material and Methods}

\section{Natural poisoning}

Cases of natural poisoning by $C$. laevigatum in cattle occurred in the municipality of Bananeiras $\left(06^{\circ} 45^{\prime} 00^{\prime \prime} \mathrm{S}\right.$, latitude and $35^{\circ} 38^{\prime} 00^{\prime \prime} \mathrm{W}$, longitude) in the Agreste Mesoregion of the State of Paraíba. This region has a tropical, rainy climate, with a dry season and a rainy season beginning in January/ February and lasting through September/October (CPRM, 2005).

Poisonings occurred in the herd of the Human, Social and Agrarian Sciences Center of the Federal University of Paraíba (UFPB), in six out of 20, three- to four-year-old crossbred cattle. The animals were grazing in two paddocks of approximately six hectares invaded by $C$. laevigatum.

Two of the six animals that died naturally were subjected to necropsy. For histopathological examination, samples of tissue from all internal organs, brains, and spinal cords was fixed in $10 \%$ buffered formalin, embedded in paraffin, cut in $4 \mu \mathrm{m}$ sections, and stained with hematoxylin and eosin (HE). A specimen of the plant was pressed, dried, authenticated, and deposited in the herbarium of the Biological Sciences Department at the Federal University of Paraíba (UFPB) (voucher \# 23096).

\section{Experimental poisoning}

In order to prove the toxicity of the plant in the region under study, an experimental poisoning was performed using the leaves and fruits of C. laevigatum collected at the paddocks where natural poisonings had occurred. Fresh green leaves and fruits were separated from the branches and immediately given in single oral doses to cattle. This experiment was approved by the Animal Ethics Committee of the Federal University of Paraíba (CEUA/UFPB) under the number $086 / 2016$.

Two clinically healthy mixed breed male bovines were used: Bovine 1 was 16 months old and Bovine 2 was 10 months old. Both animals were fasted for 12 hours. In order to prove the intoxication, high doses of the plant were used. Bovine 1 received a single dose of $35 \mathrm{~g} \mathrm{~kg}^{-1} \mathrm{BW}$ of mature leaves and fruits, while Bovine 2 received a single dose of $50 \mathrm{~g} \mathrm{~kg}^{-1} \mathrm{BW}$ of regrowth's and young fruits of $C$. laevigatum.

Clinical examinations were performed at regular intervals of six hours throughout the experiment. For both animals, blood samples were collected by jugular venipuncture using sterile vacuum, siliconecoated, blood collection tubes (Vacutainer ${ }^{\circledR}$, BD Life Sciences) without anticoagulant to obtain serum. After centrifugation for 15 minutes at 500 $\mathrm{x}$ g, serum aliquots were transferred to $2 \mathrm{~mL}$ tubes (Eppendorf) and stored at $-20{ }^{\circ} \mathrm{C}$ for analysis of enzymatic activities. Seven blood samples were collected from each experimental animal. The first collection was performed immediately prior to the administration of the plant and the second collection was performed immediately after the plant had been administered. The remaining collections were carried out during each 6-hour regular interval.

The measurement of the serum enzyme activities of aspartate aminotransferase (AST) and gammaglutamyltransferase (GGT) was performed by the kinetic method using commercial reagents (Labtest Diagnostics) and a Mindray's BS-120 automatic biochemical analyzer. 
Bovine 2, that presented severe poisoning followed by death, was necropsied and tissue samples were collected for histological examination following the same procedures used for the natural poisoning cases.

\section{Results}

\section{Natural poisoning}

The poisoning outbreak occurred in the municipality of Bananeiras, between November and December of 2014, during a prolonged dry season in two paddocks that had a shortage of forage. At the time, the shoots and young fruits of the $C$. laevigatum plants growing here showed evidence of having been consumed by the animals. The herd was composed of 20 female bovines of various ages. Six of them, three-to four-year-old, were affected and died, corresponding to a morbidity of $30 \%$ with $100 \%$ lethality.

Four animals were found dead in an advanced state of decomposition and an additional two were showing clinical signs, consisting of respiratory difficulty, drooling, jugular engorgement, muscle tremors and ataxia, which evolved to persistent recumbence and death. One of the animals was given intravenous fluid therapy (lactated Ringer's solution) and B vitamins, but died 20 hours after the onset of the signs. Necropsy was performed on both animals.

The gross lesions found in the two animals were similar. The livers were enlarged and had congestion and accentuation of the lobular pattern (Figure 1A). Petechiae and suffusion were observed in the heart, esophagus, serous and mucous membranes of the small and large intestines, and omentum (Figure 1C). In addition, hemorrhages and edema were found in the gallbladder.
The histopathologic evaluation of the livers of the two animals revealed marked coagulative centrilobular necrosis of hepatocytes, associated with intense hemorrhage. Vacuolization (degeneration) of the hepatocytes in the midzonal region was evident. In one animal, fibrosis and intense proliferation of the bile ducts of the periportal regions were also observed. Other observations in both cattle included diffuse and moderate congestion of the kidneys, engorged heart vessels and extensive subendocardial hemorrhages.

\section{Experimental poisoning}

The doses administered and the clinical course observed in the experimental poisoning by $C$. laevigatum in the two cattle are presented in Table 1. Bovine 1, which received $35 \mathrm{~g} \mathrm{~kg}^{-1} \mathrm{BW}$ of plant material, presented mild clinical signs, characterized by apathy, discreet drooling, and reduced ruminal movement, which began 24 hours and 15 minutes after administration. This animal recovered 30 hours after clinical signs were first observed.

In Bovine 2, which received $50 \mathrm{~g} \mathrm{~kg}^{-1} \mathrm{BW}$, the first clinical signs were observed 10 hours after the administration of plant material and included apathy, fecal dryness, and mild drooling. The most evident signs were observed nine hours after the onset of initial signs and included drooling with foamy saliva, hyperexcitability, head pressure against objects, opisthotonos, nystagmus, miosis, jugular and episcleral vessel engorgement, an absence of ruminal movements, and muscle tremors. Later the animal became ataxic and was unable to stay upright when stimulated to walk, experienced convulsions, and displayed sternal recumbence. Lateral recumbence with constant muscle spasms were observed before death, which occurred 11 hours and 37 minutes after the onset of clinical signs. 
Figure 1. Natural and experimental poisoning by Cestrum laevigatum in cattle. (A) Liver with accentuation of the lobular pattern and rounded edges (hepatomegaly) in a naturally poisoned animal. (B) Bovine 2, experimentally poisoned by C. laevigatum. The cut surface of the liver had lobular pattern accentuation. (C) Hemorrhagic areas in the form of petechiae and suffusions in the omentum of a naturally poisoned bovine. (D) Blood clots and striae in the cecum and colon of Bovine 2, experimentally poisoned. (E) Diffuse centrilobular coagulative necrosis forming bridges between central areas (bridge necrosis) in Bovine 2, experimentally poisoned. HE, obj. 10x. (F) Liver from panel $\mathrm{E}$ demonstrating marked coagulative necrosis of centrilobular hepatocytes and dissociation of hepatocytes in the midzonal region. HE, obj. 20x.
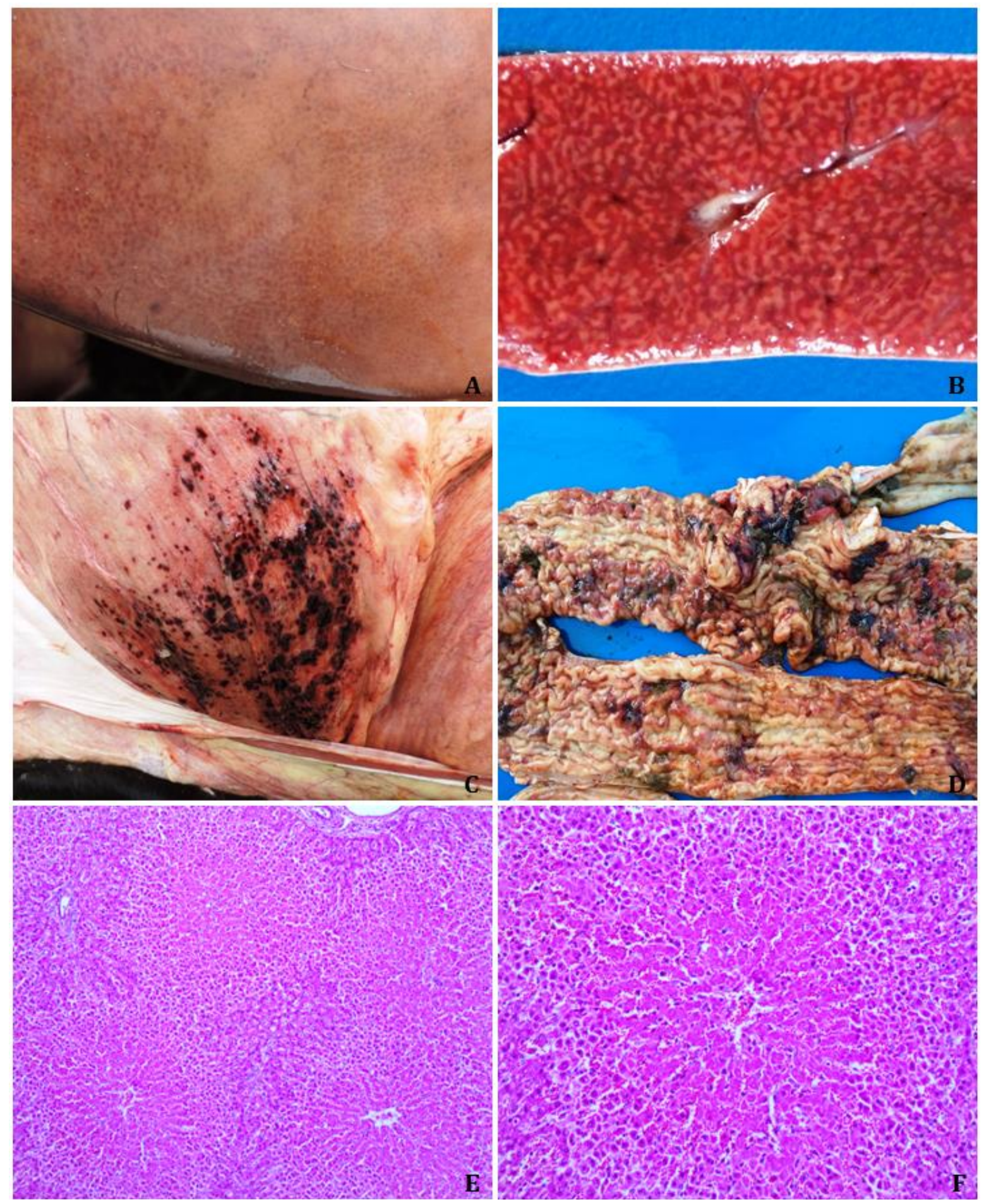
Table 1. Experimental poisoning by Cestrum laevigatum among cattle, dose administered, and outcome after initial clinical signs.

\begin{tabular}{ccccccc}
\hline & Animal & \multicolumn{2}{c}{ Plant Administration } & \multicolumn{2}{c}{ Clinical signs } \\
\hline $\mathrm{N}^{\mathrm{o}}$ & $\begin{array}{c}\text { Weight } \\
(\mathrm{kg})\end{array}$ & Age & $\begin{array}{c}\text { Amount by weight } \\
\left(\mathrm{g} \mathrm{kg}^{-1}\right)\end{array}$ & $\begin{array}{c}\text { Total dose } \\
(\mathrm{kg})\end{array}$ & Onset after dose & $\begin{array}{c}\text { Outcome after initial clinical } \\
\text { signs }\end{array}$ \\
\hline $\mathrm{B} 1$ & 191 & 16 months & 35 & 6.7 & $24 \mathrm{~h}$ and $15 \mathrm{~min}$ & $\begin{array}{c}\text { Recovery after } 30 \mathrm{~h} \\
\text { B2 }\end{array}$ \\
90 & 10 months & 50 & 4.5 & $10 \mathrm{~h}$ & Death after $11 \mathrm{~h}$ and $37 \mathrm{~min}$ \\
\hline
\end{tabular}

The measured serum activities of AST and GGT in the two experimental animals are shown in Table 2. The values of the enzymatic activities in the serum prior to administration of the plant were within the normal range. A significant increase in AST and GGT activities began 18 hours after plant administration and continued to the completion of the experiment.

Table 2. Serum enzyme activities of aspartate aminotransferase (AST) and gamma-glutamyltransferase (GGT) in both animals (B1 and B2) that were experimentally poisoned with Cestrum laevigatum with doses of $35 \mathrm{~g} \mathrm{~kg}^{-1}$ and $50 \mathrm{~g}$ $\mathrm{kg}^{-1}$, respectively.

\begin{tabular}{cccc}
\hline ANIMAL & COLLECTION & AST (U/L) & GGT (U/L) \\
\hline & Before administration & 80 & 9 \\
& After administration & 92 & 18 \\
$6 \mathrm{~h}$ & 91 & 20 \\
$12 \mathrm{~h}$ & 94 & 19 \\
$18 \mathrm{~h}$ & 217 & 27 \\
$24 \mathrm{~h}$ & 613 & 41 \\
$30 \mathrm{~h}$ & 651 & 53 \\
\hline \multirow{4}{*}{ B2 } & Before administration & 61 & 8 \\
& After administration & 75 & 12 \\
& $6 \mathrm{~h}$ & 68 & 6 \\
& $12 \mathrm{~h}$ & 51 & 9 \\
& $18 \mathrm{~h}$ & 578 & 69 \\
$24 \mathrm{~h}$ & 953 & 88 \\
& $30 \mathrm{~h}$ & 1401 & 99 \\
\hline
\end{tabular}

a Kaneko et al. (2008).

Upon necropsy of Bovine 2, we observed an enlarged liver, with rounded edges, and an accentuated lobular pattern on the subcapsular and cut surfaces of the liver (Figure 1B). The gallbladder was full and wall edema was evident. In the heart, we observed multifocal subendocardial hemorrhages in the ventricles and a single subepicardial hemorrhagic focus. In the intestines, hemorrhagic lesions were observed in the serosa and mucosa. Blood clots and hemorrhagic striae were observed in the content of the ileum, cecum and colon (Figure 1D). The ileocecal valve and the abomasum had diffuse reddening of the mucosa. Diffuse congestion was observed in the meninges.

The histologic lesions of the liver consisted of diffuse centrilobular coagulative necrosis that occasionally converged between central areas (bridge necrosis), and were associated with hemorrhage and congestion of the adjacent sinusoids (Figure $1 \mathrm{E}$ and $\mathrm{F}$ ). In the midzonal regions, we observed 
dissociation and vacuolation (degeneration) of hepatocytes. Superficial hemorrhages characterized by large numbers of free erythrocytes were observed in the intestinal lumen of the colon. The wall of the gallbladder was thickened by eosinophilic (nonproteinaceous) edema. Subendocardial hemorrhages and microthrombi formed by fibrin, red blood cells, and neutrophils were observed in the myocardium. No significant lesions were observed in the central nervous system, lungs, kidneys, lymph nodes, spleen, pancreas or adrenal glands.

\section{Discussion}

The conclusion that $C$. laevigatum was responsible for the outbreaks of acute poisoning among cattle in the Agreste region of Paraíba was based on the clinical signs, epidemiological data, necropsy findings, histopathological changes and experimental results.

The epidemiological factors that were observed, such as the low availability of forage and ingestion of sprouting plants and young fruits by young animals, have been previously reported as being the predisposing factors for outbreaks of poisoning (PESSOA et al., 2013; TOKARNIA et al., 2012). Due to the low number of experimental animals in our study, it was not possible to determine variations in plant toxicity. Although, other experimental studies were able to be reproduce the poisoning with the sprouting plant and green fruits, they were unable to do so with the mature fruits and leaves (KELLERMAN et al., 2005; THORBURN, 1934). According to Döbereiner et al. (1969) the toxic dose varies greatly from one animal to another, since some cattle died after ingestion of an experimental dose of $10 \mathrm{~g} \mathrm{~kg}^{-1} \mathrm{BW}$, while others died from a maximum dose of $50 \mathrm{~g} \mathrm{~kg}^{-1} \mathrm{BW}$. Kellerman et al. (2005) also proposed the maturity of the plant as an important factor in the variation its toxicity.

The clinical signs observed and pathological findings in our natural and experimental cases point towards acute liver failure as the cause of death. Histopathologic lesions were predominantly hepatic, characterized by centrilobular necrosis. In the experimental poisoning, necrotic lesions extended to the midzonal region and often converged with other centrilobular areas, forming bridges. Similar findings were observed in cattle and sheep experimentally poisoned with $C$. laevigatum (COUTINHO et al., 2013; LUGT et al., 1992; PEIXOTO et al., 2000) and in cases of natural poisoning in buffalo (BARBOSA et al., 2010). Centrilobular necrosis is common, because this portion of the lobe receives less oxygenated blood and is therefore susceptible to hypoxia, and has a greater mixed-function enzymatic activity capable of converting primary compounds into toxic substances (CULLEN; BROWN, 2013). Saponins (gitogenin and digitogenin) and cetrimide found in C. laevigatum have been proposed to be the toxic components in this plant (TOKARNIA et al., 2012). However, in Cestrum parqui, which causes a disease similar to that caused by $C$. laevigatum, the carboxyatractylosides parquine and carboxiparquine have been identified as the toxic components (OELRICHS et al., 1994), suggesting that $C$. laevigatum may contain similar substances.

Biochemical analyses revealed that AST and GGT enzyme activity in the serum increased significantly over time in experimentally poisoned animals. These liver function assays provide important information for monitoring the integrity of hepatocytes and the biliary system. AST enzyme activity in blood serum is higher in acute and chronic liver lesions and its main value in serum measurements is for the detection of hepatocellular lesions. GGT, being present in high concentrations in the liver, and localized mainly in epithelial cells of the bile ducts, is considered an important marker for diseases of the biliary system. Therefore, in severe liver disease, as observed in the present study, both hepatocellular and biliary lesions are often seen together (KANEKO et al., 2008).

The clinicopathological signs observed in the animals of this study were similar to those of acute 
poisoning by hepatotoxic plants that have been previously described in the literature. In Brazil, many plants can cause acute hepatic necrosis in cattle and should be considered in the differential diagnosis, including Cestrum parqui, Cestrum intermedium, Cestrum corymbosum var. hirsutum, Xanthium cavanillesii, Vernonia molissima, Vernonia rubricaulis, Sessea brasiliensis, Dodonea viscosa and Trema micranta (RIET-CORREA et al., 2009; SANTOS et al., 2008; TOKARNIA et al., 2012). However, all of these plants were neither native to Paraíba nor found in the paddocks where the outbreaks had occurred. Similar intoxications were also caused by Perreyia flavipes larvae (RAYMUNDO et al., 2009; TESSELE et al., 2012), but these were not observed in the pastures.

In the Northeastern region of Brazil, cases of toxic liver disease in ruminants have been associated with the consumption of Crotalaria retusa, Cestrum laevigatum, Tephrosia cinerea and Copernicia prunifera(BARBOSA etal., 2007). However, among these only $C$. laevigatum has been associated with acute hepatic necrosis in cattle (RIET-CORREA et al., 2009; SANTOS et al., 2008; TOKARNIA et al., 2012). Although there are other toxic plants present in the region where outbreaks of poisoning occurred, such as Crotalaria retusa, Brachiaria spp. and Lantana camara, the primary clinical sign observed in cattle poisonings by these plants is hepatogenic photosensitization (LUCENA et al., 2010; RIET-CORREA et al., 2011; TOKARNIA et al., 1999). Moreover, the number of these plants observed during the epidemiological investigation was insufficient to be the cause of the poisoning. Because neurological signs were observed in the animals of this study, it was important to consider diseases that affect the central nervous system, such as rabies, in making the differential diagnosis. However, in the histopathological evaluation of the central nervous system of two spontaneously affected animals, neither inflammatory lesions characteristic of rabies nor the presence of eosinophilic inclusion corpuscles were found (Negri corpuscles), which are observed in approximately $70 \%$ of rabies cases (BARROS et al., 2006).

\section{Conclusion}

Cestrum laevigatum was responsible for acute hepatotoxic disease among cattle in the Agreste region of Paraíba. Although not very palatable, the plant is frequently consumed by animals, especially when there is a shortage of other forage. The epidemiological conditions that are favorable to outbreaks should be avoided and the identification of C. laevigatum in pastures should be performed to establish a diagnosis. The control and eradication of the plant in pastures are advisable. Further studies should be carried out to identify the toxic compounds in the plant, the differences in toxicity between immature and mature plants, and characterization of the extent and variability in resistance among individual animals.

\section{Acknowledgments}

The authors are grateful to the Center of Human, Social and Agrarian Sciences of the Federal University of Paraíba (UFPB) for having provided the animals used in this study. This work was carried out with the support of the National Institute of Science and Technology (INCT) for the study of Control of Plant Intoxications (CNPq Proc. 573534 / 2008-0).

\section{References}

BARBOSA, J. D.; OLIVEIRA, C. M. C.; PINHEIRO, C.; LOPES, C. T. A.; MARQUIORE, D.; BRITO, M. F.; YAMASAKI, E. M.; TOKARNIA C. H. Intoxicação por Cestrum laevigatum (Solanaceae) em bubalinos. Pesquisa Veterinária Brasileira, Seropédica, v. 30, n. 12, p. 1049-1052, 2010.

BARBOSA, R. R.; RIBEIRO FILHO, M. R.; SILVA, I. P.; BLANCO, B. S. Plantas tóxicas de interesse pecuário: importância e formas de estudo. Acta Veterinária Brasílica, Mossoró, v. 1, n. 1, p. 1-7, 2007. 
BARROS, C. S. L.; DRIEMEIER, D.; DUTRA, I. S.; LEMOS, R. A. A. Doenças do sistema nervoso de bovinos no Brasil. São Paulo: Agnos, 2006. 207 p.

BRITO, M. F.; FRANÇA, T. N.; OLIVEIRA, L. I.; RAMOS, A. S.; PEIXOTO, T. C.; ARAGÃO, A. P. Intoxicação espontânea por Cestrum laevigatum em um caprino no Rio de Janeiro - relato de caso. Revista Brasileira de Medicina Veterinária, Rio de Janeiro, v. 32, n. 1, p. 55-57, 2010.

COUTINHO, L. T.; COSTA, N. A.; MENDONÇA, C. L.; AFONSO, J. A. B.; CORREA, F. R.; DANTAS, A. F. M.; SILVA, N. A. A. Intoxicação natural de bovinos leiteiros por Cestrum laevigatum (Solanaceae) no Agreste de Pernambuco - Brasil. Ciência Animal Brasileira, Goiânia, v. 14, n. 3, p. 352-359, 2013.

CULLEN, J. M.; BROWN, D. L. Sistema hepatobiliar e pâncreas exócrino. In: (Ed.). Bases da patologia em veterinária. 5. ed. Rio de Janeiro: Elsevier, 2013. p. 407-460.

DÖBEREINER, J.; TOKARNIA, C. I.; CANELLA, C. F. C. Intoxicação por Cestrum laevigatum Schlecht., a causa de mortandade em Bovinos no Estado do Rio de Janeiro. Pesquisa Agropecuária Brasileira, Brasília, v. 4, n. 1, p. 165-193, 1969.

KANEKO, J. J.; HARVEY, J. W.; BRUSS, M. L. Clinical biochemistry of domestic animals. $6^{\text {th }}$ ed. New York: Academic Press, 2008. 928 p.

KELLERMAN, T. C.; COETZER, J. A. W.; NAUDÉ, T. W.; BOTHA, C. J. Plant poisonings and mycotoxicoses of livestock in Southern África. $2^{\text {th }}$ ed. Cape Town: Oxford University Press, 2005. 310 p.

LUCENA, R. B.; RISSI, D. R.; MAIA, L. A.; FLORES, M. M.; DANTAS, A. F. M.; NOBRE, V. M. T.; RIETCORREA, F.; BARROS, C. S. L. Intoxicação por alcaloides pirrolizidínicos em ruminantes e equinos no Brasil. Pesquisa Veterinária Brasileira, Seropédica, v. 30, n. 5, p. 447-452, 2010.

VAN DER LUGT, J. J.; NEL, P. W.; KITCHING, J. P. Experimentally-induced Cestrum laevigatum (Schlecht.) poisoning in sheep. Onderstepoort Journal of Veterinary Research, Pretoria, v. 59, n. 2, p. 135-144, 1992.

MENEZES, M. M. Intoxicação experimental por Cestrum laevigatum Schlecht. em caprinos (Capra hircus). 1982. Dissertação (Mestrado em Medicina Veterinária) Universidade Federal Rural de Pernambuco, Recife.
OELRICHS, P. B.; PEARCE, C. M.; KUDO, K.; KELLY, W. R. The isolation, structure, elucidation and toxicity of the kaurene glycosides parquin and carboxiparquin in Cestrum parqui. In: (Ed.). Plants associated toxins. Wallingford: $\mathrm{CAB}$ International, 1994. p. 251256.

PEIXOTO, P. V.; BRUST, L. C.; DUARTE, M. D.; FRANÇA, T. N.; DUARTE, V. C.; BARROS, C. S. Cestrum laevigatum poisoning in goats in southeastern Brazil. Veterinary and Human Toxicology, Manhattan, v. 42, n. 1, p. 13-14, 2000.

PEREIRA, C. A. Plantas tóxicas e intoxicações na veterinária. Goiânia: UFG, 1992. 279 p.

PESSOA, C. R. M.; MEDEIROS, R. M. T.; RIETCORREA, F. Tópico de interesse geral. Importância econômica, epidemiologia e controle das intoxicações por plantas no Brasil. Pesquisa Veterinária Brasileira, Seropédica, v. 33, n. 6, p. 752-758, 2013.

RAYMUNDO, D. L.; BEZERRA JUNIOR, P. S.; BANDARRA, P. M.; SANTOS, A. S.; SONNE, L.; PAVARINI, S. P.; CORRÊA, A. M. R.; DIAS, M. M.; DRIEMEIER, D. Intoxicação espontânea pelas larvas de Perreyia flavipes em bovinos no Estado de Santa Catarina, Brasil. Ciência Rural, Santa Maria, v. 39, n. 1, p. 163-166, 2009.

RIET-CORREA, F.; BEZERRA, C. W. C.; MEDEIROS, R. M. Plantas tóxicas do Nordeste. Patos: Pallotti, 2011. $82 \mathrm{p}$.

RIET-CORREA, F.; MEDEIROS, R. M. T.; PFISTER, J.; SCHILD, A. L.; DANTAS, A. F. M. Poisonings by plants, mycotoxins and related substances in Brasilian livestock. Patos: Sociedade Vicente Pallotti, 2009. 246 p.

SANTOS, J. C. A.; RIET-CORREA, F.; SIMÕES, S. V. D.; BARROS, C. S. L. Patogênese, sinais clínicos e patologia das doenças causadas por plantas hepatotóxicas em ruminantes e equinos no Brasil. Pesquisa Veterinária Brasileira, Seropédica, v. 28, n. 1, p. 1-14, 2008.

SERVIÇO GEOLÓGICO DO BRASIL - CPRM. Paraíba - Atlas digital dos recursos hídricos subterrâneos. Recife: CPRM/PRODEEM, 2005. Disponível em: <http://www. cprm.gov.br/publique/Hidrologia/Mapas-e-Publicacoes/ Paraiba-Atlas-Digital-dos-Recursos-HidricosSubterraneos-317.html>. Acesso em: 14 mar. 2016.

TESSELE, B.; BRUM, J. S.; SCHILD, A. L.; SOARES, M. P.; BARROS, C. S. L. Sawfly larval poisoning in cattle: report on new outbreaks and brief review of the literature. Pesquisa Veterinária Brasileira, Seropédica, v. 32, n. 11, p. 1095-1102, 2012. 
THORBURN, J. A. Chase Valley Disease: Cestrum Laevigatum Schlecht., its toxic on ruminants. Onderstepoort Journal of Science and Animal Industry, Pretoria, v. 2, n. 2, p. 667-679, 1934.

TOKARNIA, C. H.; ARMIÉN, A. G.; BARROS, S. S.; PEIXOTO, P. V.; DÖBEREINER, J. Estudos complementares sobre a toxidez de Lantana camara (Verbenaceae) em bovinos. Pesquisa Veterinária Brasileira, Seropédica, v. 19, n. 3/4, p. 128-132, 1999.
TOKARNIA, C. H.; BRITO, M. F.; BARBOSA, J. D.; PEIXOTO, P. V.; DÖBEREINER, J. Plantas tóxicas do Brasil. 2. ed. Rio de Janeiro: Editora Helianthus, 2012. $566 \mathrm{p}$. 